\title{
Stability of Ceftiofur Sodium and Cefquinome Sulphate in Intravenous Solutions
}

\author{
Agnieszka Dołhań, Anna Jelińska, and Marcelina Bębenek \\ Department of Pharmaceutical Chemistry, Faculty of Pharmacy, Poznan University of Medical Sciences, \\ Grunwaldzka 6, 60-780 Poznań, Poland
}

Correspondence should be addressed to Agnieszka Dołhań; agnieszka_dolhan@wp.pl

Received 3 March 2014; Accepted 19 May 2014; Published 3 June 2014

Academic Editor: Sadhana J. Rajput

Copyright (C) 2014 Agnieszka Dołhań et al. This is an open access article distributed under the Creative Commons Attribution License, which permits unrestricted use, distribution, and reproduction in any medium, provided the original work is properly cited.

\begin{abstract}
Stability of ceftiofur sodium and cefquinome sulphate in intravenous solutions was studied. Chromatographic separation and quantitative determination were performed by using a high-performance liquid chromatography with UV-DAD detection. During the stability study, poly(vinylchloride) minibags were filled with a solution containing $5 \mathrm{mg}$ of ceftiofur sodium or cefquinome sulphate and diluted to $0.2 \mathrm{mg} / \mathrm{mL}$ with suitable intravenous solution depending on the test conditions. The solutions for the study were protected from light and stored at room temperature $\left(22^{\circ} \mathrm{C}\right)$, refrigerated $\left(6^{\circ} \mathrm{C}\right)$, frozen $\left(-20^{\circ} \mathrm{C}\right)$ for 30 days, and then thawed at room temperature. A comparison of results obtained at $22^{\circ} \mathrm{C}$ and $6^{\circ} \mathrm{C}$ for the same intravenous solutions showed that temperature as well as components of solutions and their concentration had an influence on the stability of ceftiofur sodium and cefquinome sulphate. It was found that ceftiofur sodium and cefquinome sulphate dissolved in intravenous solutions used in this study may be stored at room temperature and at $6^{\circ} \mathrm{C}$ for up to $48 \mathrm{~h}$.
\end{abstract}

\section{Introduction}

Cephalosporins, a group of $\beta$-lactam antibiotics, have been used in the treatment of various types of infections since 1954 [1]. They are characterized by a broad spectrum of antimicrobial activity and low toxicity. The mechanism of action of the cephalosporins involves inhibiting the synthesis of bacterial cell wall [2]. In a cephalosporin molecule, the $\beta$-lactam moiety is essential for antibacterial activity, but it is also very vulnerable to degradation. Products of cephalosporin degradation do not show any antimicrobial activity and may demonstrate a variety of unwanted side effects.

Ceftiofur sodium is a third-generation cephalosporin antibiotic used in veterinary medicine, approved by the Food and Drug Administration (FDA) for intramuscular injection in the treatment of certain respiratory diseases in beef cattle, dairy cattle, day-old chicken, and swine [35]. It is also applied to treat respiratory diseases in horses and ruminants [6]. Ceftiofur sodium is active against Actinobacillus pleuropneumoniae, Escherichia coli, Haemophilus parasuis, Haemophilus somnus, Pasteurella haemolytica, Pasteurella multocida, and Streptococcus suis [7-10]. Its broad spectrum of activity is attributable in part to its resistance to inactivation by bacterial $\beta$-lactamase due to the presence of a large iminomethoxy side chain [11]. The thioester bond of ceftiofur is rapidly cleaved to give desfuroylceftiofur which is further metabolized to a disulfide dimer and various desfuroylceftiofur-protein and amino acid conjugates $[12,13]$.

Cefquinome sulphate is a veterinary, parenteral, and fourth-generation cephalosporin. Its antimicrobial potency and extensive antibacterial spectrum result from the introduction of a methoxyimino-aminothiazolyl moiety into the acyl side chain. This change made it resistant to inactivation by $\beta$-lactamases [14-16].

Fourth-generation cephalosporins have a broad spectrum of antibacterial activity against Gram-positive and Gramnegative bacteria, including Pseudomonas aeruginosa and Enterobacteriaceae [17-19]. Those compounds are also easily transported across the blood-brain barrier [20-27]. They are used to treat infections of the urinary tract, lungs, skin, and soft tissues as well as in postoperative prophylaxis $[20,28]$. 
The cephalosporins are prone to degradation in aqueous solutions [29-32] and in the solid state [33-37]. Since ceftiofur sodium and cefquinome sulfate are administrated parenterally, it is essential to evaluate the influence of intravenous solutions used to dilute the drugs on their stability.

\section{Experimental}

Ceftiofur sodium was obtained from MOLEKULA (Shaftesbury, United Kingdom) and cefquinome sulphate from BePharm Ltd. (China).

Water for injections was obtained from Polpharma SA (Poland). Sodium chloride $(9 \mu \mathrm{g} / \mathrm{mL})$, glucose $(0.05 \mathrm{mg} / \mathrm{mL}$, $0.1 \mathrm{mg} / \mathrm{mL}$, and $0.2 \mathrm{mg} / \mathrm{mL}$ ), multielectrolytic isotonic fluid, pediatric fluid, and Ringer's solution were products of Baxter Manufacturing Sp. Z o. o. (Poland). Solutio Ringeri Lactate, mixture of $9 \mu \mathrm{g} / \mathrm{mL}$ sodium chloride, and $0.5 \mathrm{mg} / \mathrm{mL}$ glucose $(1: 1 \mathrm{~V} / \mathrm{V}, 1: 2 \mathrm{~V} / \mathrm{V})$ were products of Fresenius Kabi, Italy.

All other chemicals and solvents were obtained from Merck KGaA (Germany) and were of analytical or highperformance liquid chromatographic grade. High-quality pure water was prepared by using an Exil SA 67120 Millipore purification system (Millipore, Molsheim, France).

Chromatographic separation and quantitative determination were performed by using a high-performance chromatograph Shimadzu LC-20AT (ceftiofur sodium) and Shimadzu LC-6A (cefquinome sulphate). As stationary phase, LiChroCART RP-18e column $(5 \mu \mathrm{m}, 250 \mathrm{~mm} \times 4.6 \mathrm{~mm})$ (Merck, Darmstadt, Germany) and LiChroCART RP-18 $(5 \mu \mathrm{m}, 125 \mathrm{~mm} \times 4 \mathrm{~mm})$ (Merck, Darmstadt, Germany) were used for ceftiofur sodium and cefquinome sulphate, respectively. The mobile phase consisted of 22 volumes of acetonitrile and 78 volumes of phosphate buffer $(0.02 \mathrm{M}$, $\mathrm{pH}=6.0)$ for ceftiofur sodium and 10 volumes of acetonitrile and 90 volumes of phosphate buffer $(0.02 \mathrm{M}, \mathrm{pH}=$ 7.0) for cefquinome sulphate. The flow rate of the mobile phase was $1.2 \mathrm{~mL} / \mathrm{min}$ for ceftiofur sodium and $1.0 \mathrm{~mL} / \mathrm{min}$ for cefquinome sulphate. The wavelength of the UV-DAD detector was set at $292 \mathrm{~nm}$ and $268 \mathrm{~nm}$ for ceftiofur sodium and cefquinome sulphate, respectively. The HPLC method for ceftiofur sodium determination was developed by Souza et al. [38] and modified and validated in the Department of Pharmaceutical Chemistry, Poznan University of Medical Sciences [39].

\section{Sample Preparation}

During the stability study, poly(vinylchloride) minibags were filled with a solution containing $5 \mathrm{mg}$ of ceftiofur sodium or cefquinome sulphate and diluted to $0.2 \mathrm{mg} / \mathrm{mL}$ with water for injections, sodium chloride $(9 \mu \mathrm{g} / \mathrm{mL})$, glucose $(0.05 \mathrm{mg} / \mathrm{mL}$, $0.1 \mathrm{mg} / \mathrm{mL}$, and $0.2 \mathrm{mg} / \mathrm{mL}$ ), multielectrolytic isotonic fluid, pediatric fluid, Ringer's solution, Solutio Ringeri Lactate, and mixture of $9 \mu \mathrm{g} / \mathrm{mL}$ sodium chloride and $0.05 \mathrm{mg} / \mathrm{mL}$ glucose $(1: 1 \mathrm{~V} / \mathrm{V}, 1: 2 \mathrm{~V} / \mathrm{V})$, depending on the test conditions. The solutions for the study were protected from light and stored at room temperature $\left(22^{\circ} \mathrm{C}\right)$, refrigerated $\left(6^{\circ} \mathrm{C}\right)$ or frozen $\left(-20^{\circ} \mathrm{C}\right)$ for 30 days, and then thawed at room temperature.
At specified time intervals samples were collected and $50 \mu \mathrm{L}$ of the solutions was injected onto the column.

\section{Results and Discussion}

Although the HPLC method with UV detection was previously found suitable for the determination of ceftiofur sodium [39] and cefquinome sulphate [40] under the stress conditions of hydrolysis (acid and base), oxidation, photolysis, and thermal degradation, its selectivity in the presence of degradation products was confirmed (Figures 1 and 2).

Solutions of ceftiofur sodium and cefquinome sulphate were defined as stable when the substrate loss was not greater than $10 \%$ relative to the initial value. When degradation exceeded $10 \%$, the observed rate constants were determined (Tables 1, 2, and 3).

Ceftiofur sodium and cefquinome sulphate were degraded according to pseudo-first-order reactions described by the following equation:

$$
\ln \mathrm{P}_{\mathrm{it}}=\ln \mathrm{P}_{\mathrm{i} 0}-k_{\mathrm{obs}} \cdot t,
$$

where $\mathrm{P}_{\text {it }}$ and $\mathrm{P}_{\mathrm{i} 0}$ are the areas of the peaks of ceftiofur sodium or cefquinome sulphate, at time $=0$ and $t$, respectively.

The study showed that at $6^{\circ} \mathrm{C}$ ceftiofur sodium was stable (substrate loss not greater than $10 \%$ ) in water for injection, $9 \mu \mathrm{g} / \mathrm{mL}$ sodium chloride, $0.05 \mathrm{mg} / \mathrm{mL}$ and $0.1 \mathrm{mg} / \mathrm{mL}$ glucose, mixture of $9 \mu \mathrm{g} / \mathrm{mL}$ sodium chloride and $0.05 \mathrm{mg} / \mathrm{mL}$ glucose $(1: 1 \mathrm{~V} / \mathrm{V}$ and $1: 2 \mathrm{~V} / \mathrm{V})$, Ringer's solution, Solutio Ringeri Lactate, multielectrolytic isotonic fluid, and pediatric fluid. The degradation of ceftiofur sodium in $0.2 \mathrm{mg} / \mathrm{mL}$ glucose exceeded $0.1 \mathrm{mg} / \mathrm{mL}$ of the initial concentration. At $-20^{\circ} \mathrm{C}$, all solutions of ceftiofur sodium were found to be stable.

At $22^{\circ} \mathrm{C}$, ceftiofur sodium was the most stable in Ringer's solution and water for injection, with $92.60 \%$ and $91.92 \%$ of the initial concentration after 23 days of testing, respectively. It was the most unstable in $0.2 \mathrm{mg} / \mathrm{mL}$ glucose, with $72.86 \%$ of the initial concentration after 23 days. At $22^{\circ} \mathrm{C}$ in $9 \mu \mathrm{g} / \mathrm{mL}$ sodium chloride, $0.05 \mathrm{mg} / \mathrm{mL}$ glucose, mixture of $9 \mu \mathrm{g} / \mathrm{mL}$ sodium chloride and $0.05 \mathrm{mg} / \mathrm{mL}$ glucose $(1: 1 \mathrm{~V} / \mathrm{V})$, multielectrolytic isotonic fluid, and pediatric fluid after 2 days of incubation, there were no changes in the concentrations. As a precipitate was formed after 6 days of incubation, the experiment was abandoned.

At $6^{\circ} \mathrm{C}$, ceftiofur sodium was the most stable in pediatric fluid (after 28 days with $98.12 \%$ of the initial concentration) and the most unstable in $0.2 \mathrm{mg} / \mathrm{mL}$ glucose (after 28 days with $89.59 \%$ of the initial concentration). After 30 days of incubation at $-20^{\circ} \mathrm{C}$, ceftiofur sodium was the most stable in pediatric fluid (after 30 days with $98.98 \%$ of the initial concentration) and the most unstable in $9 \mu \mathrm{g} / \mathrm{mL}$ sodium chloride (after 30 days with $89.99 \%$ of the initial concentration).

The study demonstrated that at $6^{\circ} \mathrm{C}$ cefquinome sulphate was stable (substrate loss not greater than $10 \%$ for 6 days) in water for injection, $9 \mu \mathrm{g} / \mathrm{mL}$ sodium chloride, $0.05 \mathrm{mg} / \mathrm{mL}$ and $0.1 \mathrm{mg} / \mathrm{mL}$ glucose, mixture of $9 \mu \mathrm{g} / \mathrm{mL}$ sodium chloride and $0.05 \mathrm{mg} / \mathrm{mL}$ glucose $(1: 1 \mathrm{~V} / \mathrm{V})$, multielectrolytic isotonic 


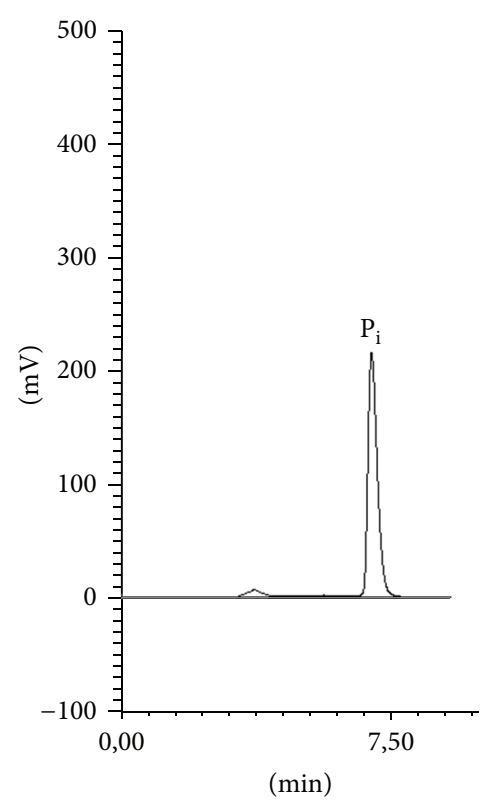

(a)

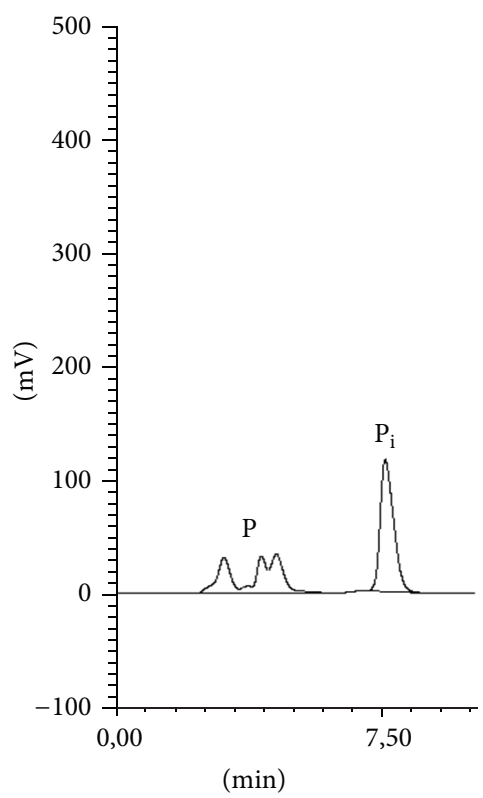

(b)

FIGURE 1: HPLC chromatogram of ceftiofur sodium after incubation (a) $0 \mathrm{~h}$ and (b) 23 days in $0.2 \mathrm{mg} / \mathrm{mL}$ glucose in $22^{\circ} \mathrm{C}\left(\mathrm{P}_{\mathrm{i}}\right.$ : ceftiofur sodium, P: degradation products).

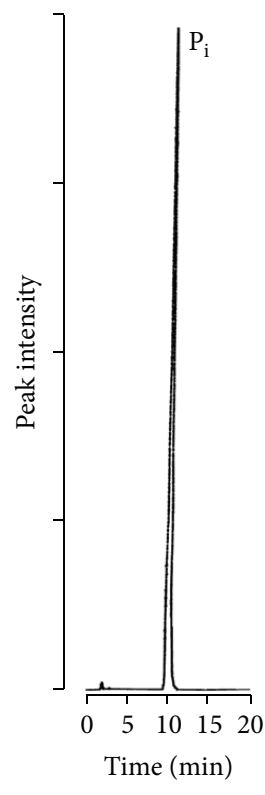

(a)

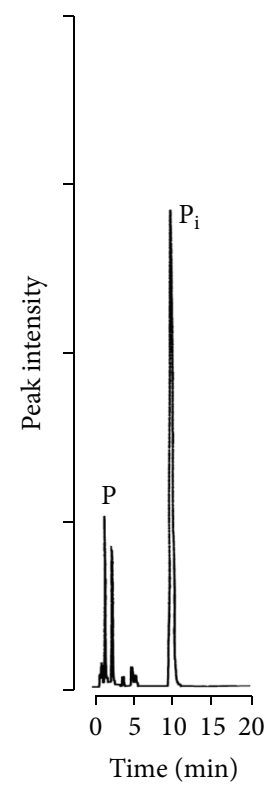

(b)

FiguRE 2: HPLC chromatogram of cefquinome sulphate after incubation (a) $0 \mathrm{~h}$ and (b) 6 days in $0.2 \mathrm{mg} / \mathrm{mL}$ glucose in $22^{\circ} \mathrm{C}$ ( $\mathrm{P}_{\mathrm{i}}$ : cefquinome sulphate, P: degradation products).

fluid, and pediatric fluid. All the solutions were stable at $6^{\circ} \mathrm{C}$ and after 30 days of incubation at $-20^{\circ} \mathrm{C}$.

At $22^{\circ} \mathrm{C}$, cefquinome sulphate was the most stable in $9 \mu \mathrm{g} / \mathrm{mL}$ sodium chloride (after 6 days of incubation, no changes in the concentrations were observed) and the most unstable in $0.1 \mathrm{mg} / \mathrm{mL}$ glucose (after 6 days with $75.34 \%$ of the initial concentration). At $6^{\circ} \mathrm{C}$, it was the most stable in multielectrolytic isotonic fluid (after 10 days with $93.29 \%$ of the initial concentration) and pediatric fluid (after 9 days with $93.69 \%$ of the concentration). At $6^{\circ} \mathrm{C}$, it was the most unstable in $0.1 \mathrm{mg} / \mathrm{mL}$ glucose (after 9 days with $89.99 \%$ of the initial concentration). 
TABLE 1: Stability of ceftiofur sodium stored in poly(vinyl chloride) minibags.

\begin{tabular}{|c|c|c|c|c|c|}
\hline \multicolumn{3}{|c|}{$22^{\circ} \mathrm{C}$} & \multicolumn{3}{|c|}{$6^{\circ} \mathrm{C}$} \\
\hline Intravenous solution & $t$ (day) & $c(\%)$ & Intravenous solution & $t$ (day) & $c(\%)$ \\
\hline \multirow{4}{*}{ Water for injection } & 0 & 100.00 & \multirow{4}{*}{ Water for injection } & 0 & 100.00 \\
\hline & 2 & 98.85 & & 3 & 99.02 \\
\hline & 6 & 97.62 & & 12 & 97.13 \\
\hline & 23 & 91.92 & & 28 & 94.23 \\
\hline \multirow{4}{*}{ Glucose $0.1 \mathrm{mg} / \mathrm{mL}$} & 0 & 100.00 & \multirow{4}{*}{ Glucose $0.1 \mathrm{mg} / \mathrm{mL}$} & 0 & 100.00 \\
\hline & 2 & 98.40 & & 3 & 99.28 \\
\hline & 6 & 95.61 & & 12 & 97.21 \\
\hline & 23 & 82.87 & & 28 & 91.35 \\
\hline \multirow{4}{*}{ Glucose $0.2 \mathrm{mg} / \mathrm{mL}$} & 0 & 100.00 & \multirow{4}{*}{ Glucose $0.2 \mathrm{mg} / \mathrm{mL}$} & 0 & 100.00 \\
\hline & 2 & 97.73 & & 3 & 98.39 \\
\hline & 6 & 92.27 & & 12 & 94.96 \\
\hline & 23 & 72.86 & & 28 & 89.59 \\
\hline \multirow{4}{*}{$\begin{array}{l}\text { Mixture of } 9 \mu \mathrm{g} / \mathrm{mL} \\
\text { sodium chloride and } \\
0.05 \mathrm{mg} / \mathrm{mL} \text { glucose } \\
(1: 2 \mathrm{~V} / \mathrm{V})\end{array}$} & 0 & 100.00 & \multirow{4}{*}{$\begin{array}{c}\text { Mixture of } 9 \mu \mathrm{g} / \mathrm{mL} \\
\text { sodium chloride and } \\
0.05 \mathrm{mg} / \mathrm{mL} \text { glucose } \\
(1: 2 V / V)\end{array}$} & 0 & 100.00 \\
\hline & 2 & 98.14 & & 3 & 99.32 \\
\hline & 6 & 96.10 & & 12 & 98.80 \\
\hline & 23 & 87.33 & & 28 & 97.05 \\
\hline \multirow{4}{*}{ Solutio Ringeri } & 0 & 100.00 & \multirow{4}{*}{ Solutio Ringeri } & 0 & 100.00 \\
\hline & 2 & 98.71 & & 3 & 99.14 \\
\hline & 6 & 97.78 & & 12 & 97.76 \\
\hline & 23 & 92.60 & & 28 & 95.77 \\
\hline \multirow{4}{*}{ Solutio Ringeri Lactate } & 0 & 100.00 & \multirow{4}{*}{ Solutio Ringeri Lactate } & 0 & 100.00 \\
\hline & 2 & 99.18 & & 3 & 99.46 \\
\hline & 6 & 96.30 & & 12 & 98.81 \\
\hline & 23 & 87.65 & & 28 & 97.56 \\
\hline \multirow{4}{*}{$\begin{array}{l}\text { Multielectrolytic } \\
\text { isotonic fluid }\end{array}$} & 0 & 100.00 & \multirow{4}{*}{$\begin{array}{l}\text { Multielectrolytic } \\
\text { isotonic fluid }\end{array}$} & 0 & 100.00 \\
\hline & 2 & 100.16 & & 3 & 99.12 \\
\hline & 6 & Precipitation & & 12 & 98.04 \\
\hline & & & & 28 & 95.11 \\
\hline \multirow{4}{*}{ Pediatric fluid } & 0 & 100.00 & \multirow{4}{*}{ Pediatric fluid } & 0 & 100.00 \\
\hline & 2 & 99.56 & & 3 & 99.65 \\
\hline & 6 & Precipitation & & 12 & 99.21 \\
\hline & & & & 28 & 98.12 \\
\hline \multirow{4}{*}{$\begin{array}{l}\text { Sodium chloride } \\
9 \mu \mathrm{g} / \mathrm{mL}\end{array}$} & 0 & 100.00 & \multirow{4}{*}{$\begin{array}{l}\text { Sodium chloride } \\
\qquad 9 \mu \mathrm{g} / \mathrm{mL}\end{array}$} & 0 & 100.00 \\
\hline & 2 & 100.02 & & 3 & 99.61 \\
\hline & 6 & Precipitation & & 12 & 99.02 \\
\hline & & & & 28 & 97.88 \\
\hline \multirow{4}{*}{ Glucose $0.05 \mathrm{mg} / \mathrm{mL}$} & 0 & 100.00 & \multirow{4}{*}{ Glucose $0.05 \mathrm{mg} / \mathrm{mL}$} & 0 & 100.00 \\
\hline & 2 & 100.15 & & 3 & 99.02 \\
\hline & 6 & Precipitation & & 12 & 97.88 \\
\hline & & & & 28 & 94.79 \\
\hline \multirow{4}{*}{$\begin{array}{l}\text { Mixture of } 9 \mu \mathrm{g} / \mathrm{mL} \\
\text { sodium chloride and } \\
0.05 \mathrm{mg} / \mathrm{mL} \text { glucose } \\
(1: 1 \mathrm{~V} / \mathrm{V})\end{array}$} & 0 & 100.00 & Mixture of $9 \mu \mathrm{g} / \mathrm{mL}$ & 0 & 100.00 \\
\hline & 2 & 99.77 & sodium chloride and & 3 & 99.44 \\
\hline & 6 & Precipitation & $0.05 \mathrm{mg} / \mathrm{mL}$ glucose & 12 & 98.72 \\
\hline & & & & 28 & 96.15 \\
\hline
\end{tabular}

$c(\%)$ : percent of initial concentration. 
TABLE 2: Stability of cefquinome sulphate stored in poly(vinyl chloride) minibags.

\begin{tabular}{|c|c|c|c|c|c|}
\hline \multicolumn{3}{|c|}{$22^{\circ} \mathrm{C}$} & \multicolumn{3}{|c|}{$6^{\circ} \mathrm{C}$} \\
\hline Intravenous solution & $t$ (day) & $c(\%)$ & Intravenous solution & $t$ (day) & $c(\%)$ \\
\hline \multirow{4}{*}{ Water for injection } & 0 & 100.00 & \multirow{4}{*}{ Water for injection } & 0 & 100.00 \\
\hline & 1 & 98.28 & & 1 & 98.52 \\
\hline & 3 & 96.42 & & 3 & 96.53 \\
\hline & 6 & 91.93 & & 9 & 91.92 \\
\hline \multirow{4}{*}{$\begin{array}{l}\text { Sodium chloride } \\
9 \mu \mathrm{g} / \mathrm{mL}\end{array}$} & 0 & 100.00 & \multirow{4}{*}{$\begin{array}{l}\text { Sodium chloride } \\
\qquad 9 \mu \mathrm{g} / \mathrm{mL}\end{array}$} & 0 & 100.00 \\
\hline & 1 & 99.50 & & 1 & 98.24 \\
\hline & 3 & 99.90 & & 3 & 96.30 \\
\hline & 6 & 99.84 & & 9 & 91.42 \\
\hline \multirow{4}{*}{ Glucose $0.05 \mathrm{mg} / \mathrm{mL}$} & 0 & 100.00 & \multirow{4}{*}{ Glucose $0.2 \mathrm{mg} / \mathrm{mL}$} & 0 & 100.00 \\
\hline & 1 & 98.20 & & 1 & 98.12 \\
\hline & 3 & 89.75 & & 3 & 95.02 \\
\hline & 6 & 78.88 & & 9 & 90.81 \\
\hline \multirow{4}{*}{ Glucose $0.1 \mathrm{mg} / \mathrm{mL}$} & 0 & 100.00 & \multirow{4}{*}{ Glucose $0.1 \mathrm{mg} / \mathrm{mL}$} & 0 & 100.0 \\
\hline & 1 & 94.73 & & 1 & 98.53 \\
\hline & 3 & 85.69 & & 3 & 96.30 \\
\hline & 6 & 75.34 & & 9 & 89.99 \\
\hline \multirow{4}{*}{ Glucose $0.2 \mathrm{mg} / \mathrm{mL}$} & 0 & 100.00 & \multirow{4}{*}{ Glucose $200 \mathrm{~g} / \mathrm{L}$} & 0 & 100.00 \\
\hline & 1 & 96.46 & & 1 & 98.30 \\
\hline & 3 & 91.14 & & 3 & 96.15 \\
\hline & 6 & 82.41 & & 9 & 92.10 \\
\hline \multirow{4}{*}{$\begin{array}{l}\text { Mixture of } 9 \mu \mathrm{g} / \mathrm{L} \\
\text { sodium chloride and } \\
0.05 \mathrm{mg} / \mathrm{mL} \text { glucose } \\
(1: 1 V / V)\end{array}$} & 0 & 100.00 & \multirow{4}{*}{$\begin{array}{c}\text { Mixture of } 9 \mu \mathrm{g} / \mathrm{mL} \\
\text { sodium chloride and } \\
0.05 \mathrm{mg} / \mathrm{mL} \text { glucose } \\
(1: 1 \mathrm{~V} / \mathrm{V})\end{array}$} & 0 & 100.00 \\
\hline & 1 & 99.48 & & 1 & 99.72 \\
\hline & 3 & 96.41 & & 3 & 97.32 \\
\hline & 6 & 91.01 & & 9 & 96.41 \\
\hline \multirow{4}{*}{$\begin{array}{l}\text { Mixture of } 9 \mu \mathrm{g} / \mathrm{mL} \\
\text { sodium chloride and } \\
0.05 \mathrm{mg} / \mathrm{mL} \text { glucose } \\
(1: 2 \mathrm{~V} / \mathrm{V})\end{array}$} & 0 & 100.00 & \multirow{4}{*}{$\begin{array}{c}\text { Mixture of } 9 \mu \mathrm{g} / \mathrm{mL} \\
\text { sodium chloride and } \\
0.05 \mathrm{mg} / \mathrm{mL} \text { glucose } \\
(1: 2 \mathrm{~V} / \mathrm{V})\end{array}$} & 0 & 100.00 \\
\hline & 1 & 96.41 & & 1 & 99.55 \\
\hline & 3 & 92.06 & & 3 & 98.38 \\
\hline & 6 & 81.73 & & 9 & 92.27 \\
\hline \multirow{4}{*}{ Solutio Ringeri } & 0 & 100.00 & \multirow{4}{*}{ Solutio Ringeri } & 0 & 100.00 \\
\hline & 1 & 97.89 & & 1 & 99.78 \\
\hline & 3 & 92.27 & & 3 & 97.58 \\
\hline & 6 & 82.86 & & 9 & 91.99 \\
\hline \multirow{4}{*}{ Solutio Ringeri Lactate } & 0 & 100.00 & \multirow{4}{*}{ Solutio Ringeri Lactate } & 0 & 100.00 \\
\hline & 1 & 97.88 & & 1 & 98.66 \\
\hline & 3 & 92.70 & & 3 & 98.44 \\
\hline & 6 & 86.12 & & 9 & 93.56 \\
\hline \multirow{4}{*}{$\begin{array}{l}\text { Multielectrolytic } \\
\text { isotonic fluid }\end{array}$} & 0 & 100.00 & \multirow{4}{*}{$\begin{array}{l}\text { Multielectrolytic } \\
\text { isotonic fluid }\end{array}$} & 0 & 100.00 \\
\hline & 1 & 98.14 & & 1 & 99.95 \\
\hline & 3 & 95.72 & & 3 & 98.11 \\
\hline & 6 & 92.13 & & 9 & 95.13 \\
\hline \multirow{4}{*}{ Pediatric fluid } & 0 & 100.00 & & 0 & 100.00 \\
\hline & 1 & 97.13 & Pediatric fluid & 1 & 98.16 \\
\hline & 3 & 93.88 & & 3 & 96.16 \\
\hline & 6 & 87.81 & & 9 & 93.69 \\
\hline
\end{tabular}

$c$ (\%): percent of initial concentration. 
TABLE 3: Stability of ceftiofur sodium and cefquinome sulphate stored for 30 days at $-20^{\circ} \mathrm{C}$ in poly(vinyl chloride) minibags.

\begin{tabular}{|c|c|c|c|c|}
\hline \multirow{2}{*}{ Solution } & \multicolumn{2}{|c|}{ Ceftiofur sodium } & \multicolumn{2}{|c|}{ Cefquinome sulphate } \\
\hline & $t$ (day) & $c(\%)$ & $t$ (day) & $c(\%)$ \\
\hline \multirow{2}{*}{ Water for injection } & 0 & 100.00 & 0 & 100.00 \\
\hline & 30 & 93.81 & 30 & 95.10 \\
\hline \multirow{2}{*}{ Sodium chloride $9 \mu \mathrm{g} / \mathrm{mL}$} & 0 & 100.00 & 0 & 100.00 \\
\hline & 30 & 89.99 & 30 & 98.93 \\
\hline \multirow{2}{*}{ Glucose $0.05 \mathrm{mg} / \mathrm{mL}$} & 0 & 100.00 & 0 & 100.00 \\
\hline & 30 & 94.34 & 30 & 95.97 \\
\hline \multirow{2}{*}{ Glucose $0.1 \mathrm{mg} / \mathrm{mL}$} & 0 & 100.00 & 0 & 100.00 \\
\hline & 30 & 98.10 & 30 & 94.32 \\
\hline \multirow{2}{*}{ Glucose $0.2 \mathrm{mg} / \mathrm{mL}$} & 0 & 100.00 & 0 & 100.00 \\
\hline & 30 & 94.89 & 30 & 99.06 \\
\hline \multirow{2}{*}{$\begin{array}{l}\text { Mixture of } 9 \mu \mathrm{g} / \mathrm{mL} \text { sodium chloride and } \\
0.05 \mathrm{mg} / \mathrm{mL} \text { glucose }(1: 1 \mathrm{~V} / \mathrm{V})\end{array}$} & 0 & 100.00 & 0 & 100.00 \\
\hline & 30 & 97.60 & 30 & 100.00 \\
\hline \multirow{2}{*}{$\begin{array}{l}\text { Mixture of } 9 \mu \mathrm{g} / \mathrm{mL} \text { sodium chloride and } \\
0.05 \mathrm{mg} / \mathrm{mL} \text { glucose }(1: 2 \mathrm{~V} / \mathrm{V})\end{array}$} & 0 & 100.00 & 0 & 100.00 \\
\hline & 30 & 97.99 & 30 & 92.89 \\
\hline \multirow{2}{*}{ Solutio Ringeri } & 0 & 100.00 & 0 & 100.00 \\
\hline & 30 & 97.80 & 30 & 99.51 \\
\hline \multirow{2}{*}{ Solutio Ringeri Lactate } & 0 & 100.00 & 0 & 100.00 \\
\hline & 30 & 96.76 & 30 & 100.00 \\
\hline \multirow{2}{*}{ Multielectrolytic isotonic fluid } & 0 & 100.00 & 0 & 100.00 \\
\hline & 30 & 96.35 & 30 & 98.46 \\
\hline \multirow{2}{*}{ Pediatric fluid } & 0 & 100.00 & 0 & 100.00 \\
\hline & 30 & 98.98 & 30 & 100.00 \\
\hline
\end{tabular}

$c(\%)$ : percent of initial concentration.

At $-20^{\circ} \mathrm{C}$, cefquinome sulphate was the most stable in a mixture of $9 \mu \mathrm{g} / \mathrm{mL}$ sodium chloride and $0.05 \mathrm{mg} / \mathrm{mL}$ glucose $(1: 1 \mathrm{~V} / \mathrm{V})$, Ringer's lactate solution, and pediatric fluid (no changes in the concentrations were observed after 30 days of incubation). It was the most unstable in a mixture of $9 \mu \mathrm{g} / \mathrm{mL}$ sodium chloride and $0.05 \mathrm{mg} / \mathrm{mL}$ glucose $(2: 1 \mathrm{~V} / \mathrm{V})$ (after 30 days with $92.89 \%$ of the initial concentration).

A comparison of results obtained at $22^{\circ} \mathrm{C}$ and $6^{\circ} \mathrm{C}$ for the same intravenous solutions showed that temperature as well as components of solutions and their concentration had an influence on the stability of ceftiofur sodium and cefquinome sulphate.

It was found that ceftiofur sodium and cefquinome sulphate dissolved in intravenous solutions used in those studies may be stored at room temperature and at $6^{\circ} \mathrm{C}$ for up to $48 \mathrm{~h}$.

\section{Conflict of Interests}

The authors declare that there is no conflict of interests regarding the publication of this paper.

\section{References}

[1] L. Zaffiri, J. Gardner, and L. H. Toledo-Pereyra, "History of antibiotics: from salvarsan to cephalosporins," Journal of Investigative Surgery, vol. 25, no. 2, pp. 67-77, 2012.
[2] P. Zalewski and J. Cielecka-Piontek, "Cefoselina-nowa cefalosporyna czwartej generacji," Annales Academiae Medicae Silesiensis, vol. 65, pp. 77-81, 2011.

[3] Food and Drug Administration, "Animal drugs, feeds and relative products-ceftiofur sterile powder," Federal Register, vol. 53, pp. 5369-5370, 1988.

[4] Food and Drug Administration, "Implantation injectable dosage form, animal drugs not subject to certification-ceftiofur sterile powder," Federal Register, vol. 56, pp. 112-119, 1991.

[5] Food and Drug Administration, "Implantation injectable dosage form, new animal drugs-ceftiofur sterile powder for injection," Federal Register, vol. 57, p. 41862, 1992.

[6] R. E. Hornish and S. F. Kotarski, "Cephalosporins in veterinary medicine-ceftiofur use in food animals," Current Topics in Medicinal Chemistry, vol. 2, no. 7, pp. 717-731, 2002.

[7] S. A. Salmon, J. L. Watts, C. A. Case, L. J. Hoffman, H. C. Wegener, and R. J. Yancey Jr., "Comparison of MICs of ceftiofur and other antimicrobial agents against bacterial pathogens of swine from the United States, Canada, and Denmark," Journal of Clinical Microbiology, vol. 33, no. 9, pp. 2435-2444, 1995.

[8] R. J. Erskine, R. C. Wilson, J. W. Tyler, K. A. McClure, R. S. Nelson, and H. J. Spears, "Ceftiofur distribution in serum and milk from clinically normal cows and cows with experimental Escherichia coli-induced mastitis," American Journal of Veterinary Research, vol. 56, no. 4, pp. 481-485, 1995.

[9] C. Stanek and J. Kofler, "On the treatment of complicated septic disorders of the bovine digit, using a combination of surgical therapy and application of Sodium-Ceftiofur," Tierarztliche 
Praxis Ausgabe G: Grosstiere/Nutztiere, vol. 26, no. 6, pp. 314317, 1998.

[10] H. J. Wisselink, K. T. Veldman, C. Van Den Eede, S. A. Salmon, and D. J. Mevius, "Quantitative susceptibility of Streptococcus suis strains isolated from diseased pigs in seven European countries to antimicrobial agents licenced in veterinary medicine," Veterinary Microbiology, vol. 113, no. 1-2, pp. 73-82, 2006.

[11] P. S. Jaglan, M. F. Kubicek, T. S. Arnold et al., "Metabolism of ceftiofur. Nature of urinary and plasma metabolites in rats and cattle," Journal of Agricultural and Food Chemistry, vol. 37, no. 4, pp. 1112-1118, 1989.

[12] P. S. Jaglan, B. L. Cox, T. S. Arnold, M. F. Kubicek, D. J. Stuart, and T. J. Gilbertson, "Liquid chromatographic determination of desfuroylceftiofur metabolite of ceftiofur as residue in cattle plasma," Journal of the Association of Official Analytical Chemists, vol. 73, no. 1, pp. 26-30, 1990.

[13] M. G. Beconi-Barker, R. D. Roof, L. Millerioux et al., "Determination of ceftiofur and its desfuroylceftioufur-related metabolites in swine tissues by high-performance liquid chromatography," Journal of Chromatography B: Biomedical Applications, vol. 673 , no. 2, pp. 231-244, 1995.

[14] W. F. Marshall and J. E. Blair, “The cephalosporins," Mayo Clinic Proceedings, vol. 74, no. 2, pp. 187-195, 1999.

[15] W. Dürckheimer, F. Adam, G. Fischer, and R. Kirrstetter, "Recent developments in the field of cephem antibiotics," Advances in Drug Research, vol. 17, pp. 61-234, 1988.

[16] H. C. Neu, "Clinical uses of cephalosporins," The Lancet, vol. 2, no. 8292, pp. 252-255, 1982.

[17] T. Kuriyama, T. Karasawa, K. Nakagawa, S. Nakamura, and E. Yamamoto, "Antimicrobial susceptibility of major pathogens of orofacial odontogenic infections to $11 \beta$-lactam antibiotics," Oral Microbiology and Immunology, vol. 17, no. 5, pp. 285-289, 2002.

[18] M. W. Climo, S. M. Markowitz, D. S. Williams, C. G. HaleCooper, and G. L. Archer, "Comparison of the in-vitro and in-vivo efficacy of FK037, vancomycin, imipenem and nafcillin against staphylococcal species," Journal of Antimicrobial Chemotherapy, vol. 40, no. 1, pp. 59-66, 1997.

[19] H. C. Neu, N. X. Chin, and H. B. Huang, "In vitro activity and $\beta$-lactamase stability of FK-037, a parenteral cephalosporin," Antimicrobial Agents and Chemotherapy, vol. 37, no. 3, pp. 566$573,1993$.

[20] H. S. Sader and R. N. Jones, "The fourth-generation cephalosporins: antimicrobial activity and spectrum definitions using cefpirome as an example," Antimicrobic Newsletter, vol. 9, no. 2, pp. 9-16, 1993.

[21] J. Garau, W. Wilson, M. Wood, and J. Carlet, "Fourth-generation cephalosporins: a review of in vitro activity, pharmacokinetics, pharmacodynamics and clinical utility," Clinical Microbiology and Infection, vol. 3, no. 1, pp. S87-S101, 1997.

[22] Q. Yang, H. Wang, M. Chen et al., "Surveillance of antimicrobial susceptibility of aerobic and facultative Gram-negative bacilli isolated from patients with intra-abdominal infections in China: the 2002-2009 Study for Monitoring Antimicrobial Resistance Trends (SMART)," International Journal of Antimicrobial Agents, vol. 36, no. 6, pp. 507-512, 2010.

[23] M. S. Barber, U. Giesecke, A. Reichert, and W. Minas, "Industrial enzymatic production of cephalosporin-based beta-lactams,"
Advances in Biochemical Engineering/Biotechnology, vol. 88, pp. 179-215, 2004.

[24] A. G. Kambaroudis, S. Papadopoulos, M. Christodoulidou, and T. Gerasimidis, "Perioperative use of antibiotics in intra-abdominal surgical infections," Surgical Infections, vol. 11, no. 6, pp. 535-544, 2010.

[25] G. Bonfiglio and F. Marchetti, "In vitro activity of ceftazidime, cefepime and imipenem on 1,005 Pseudomonas aeruginosa clinical isolates either susceptible or resistant to beta-lactams," Chemotherapy, vol. 46, no. 4, pp. 229-234, 2000.

[26] J. Garau, "The clinical potential of fourth-generation cephalosporins," Diagnostic Microbiology and Infectious Disease, vol. 31, no. 3, pp. 479-480, 1998.

[27] W. R. Wilson, "The role of fourth-generation cephalosporins in the treatment of serious infectious diseases in hospitalized patients," Diagnostic Microbiology and Infectious Disease, vol. 31, no. 3, pp. 473-477, 1998.

[28] Ł. Hońdo, Od odkrycia antybiotyków do Europejskiego Dnia Wiedzy o Antybiotykach, Aptekarz Polski, 2009.

[29] G. Patel and S. Rajput, "Stress degradation studies on cefpodoxime proxetil and development of a validated stabilityindicating HPLC method," Acta Chromatographica, vol. 23, no. 2, pp. 215-234, 2011.

[30] Y. Ikeda, J. Ban, T. Ishikawa, S. Hashiguchi, S. Urayama, and H. Horibe, "Stability and stabilization studies of TAK-599 (ceftaroline fosamil), a novel N-phosphono type prodrug of anti-methicillin resistant Staphylococcus aureus cephalosporin T-91825," Chemical and Pharmaceutical Bulletin, vol. 56, no. 10, pp. 1406-1411, 2008.

[31] T. Sugioka, T. Asano, Y. Chikaraishi et al., "Stability and degradation pattern of cefpirome (HR 810) in aqueous solution," Chemical and Pharmaceutical Bulletin, vol. 38, no. 7, pp. 19982002, 1990.

[32] J. O. Fubara and R. E. Notari, "A kinetic oxymoron: concentration-dependent first-order rate constants for hydrolysis of ceftazidime," Journal of Pharmaceutical Sciences, vol. 87, no. 1, pp. 53-58, 1998.

[33] B. Medenecka, A. Jelińska, M. Zaj,c, M. Bałdyka, K. Juszkiewicz, and I. Oszczapowicz, "Stability of the crystalline form of cefaclor monohydrate and its pharmaceutical preparations," Acta Poloniae Pharmaceutica: Drug Research, vol. 66, no. 5, pp. 563-569, 2009.

[34] A. Jelińska, B. Medenecka, M. Zajc, and M. Knajsiak, "The stability of cefprozil in oral suspension CEFZIL," Acta Poloniae Pharmaceutica: Drug Research, vol. 65, no. 2, pp. 261-265, 2008.

[35] M. Zajac, A. Jeliñska, and P. Zalewski, "Stability of ceftriaxone disodium in biotrakson and tartriakson," Acta Poloniae Pharmaceutica: Drug Research, vol. 62, no. 2, pp. 89-94, 2005.

[36] A. Jelińska, I. Dudzińska, M. Zając, I. Oszczapowicz, and W. Krzewski, "The stability of Cefuroxime axetil in tablets," Acta Poloniae Pharmaceutica, vol. 62, pp. 183-187, 2005.

[37] P. Zalewski, J. Cielecka-Piontek, P. Garbacki, A. Jelińska, and M. Karaåniewicz-ŁAda, "Stability-indicating HPLC method for the determination of Cefcapene pivoxil," Chromatographia, vol. 76, no. 7-8, pp. 387-391, 2013.

[38] M. J. E. Souza, D. R. Nogueira, L. M. Silva, M. Z. Arend, P. S. Souza Filho, and A. M. Bergold, "Development and validation of an HPLC method for determination of ceftiofur sodium," Chromatographia, vol. 65, no. 7-8, pp. 401-406, 2007. 
[39] P. Garbacki, A. Dołhań, and A. Jelińska, Opracowanie metody HPLC do badania trwałości ceftiofuru sodowego, XXII Naukowy Zjazd Polskiego Towarzystwa Farmaceutycznego, Białystok, Poland, 2013.

[40] A. Dołhań, A. Jelińska, and M. Manuszewska, "Manuszewska, Stability-indicating HPLC method for the determination of cefquinome sulphate," Acta Poloniae Pharmaceutica, vol. 71, no. 2, pp. 249-264, 2014. 

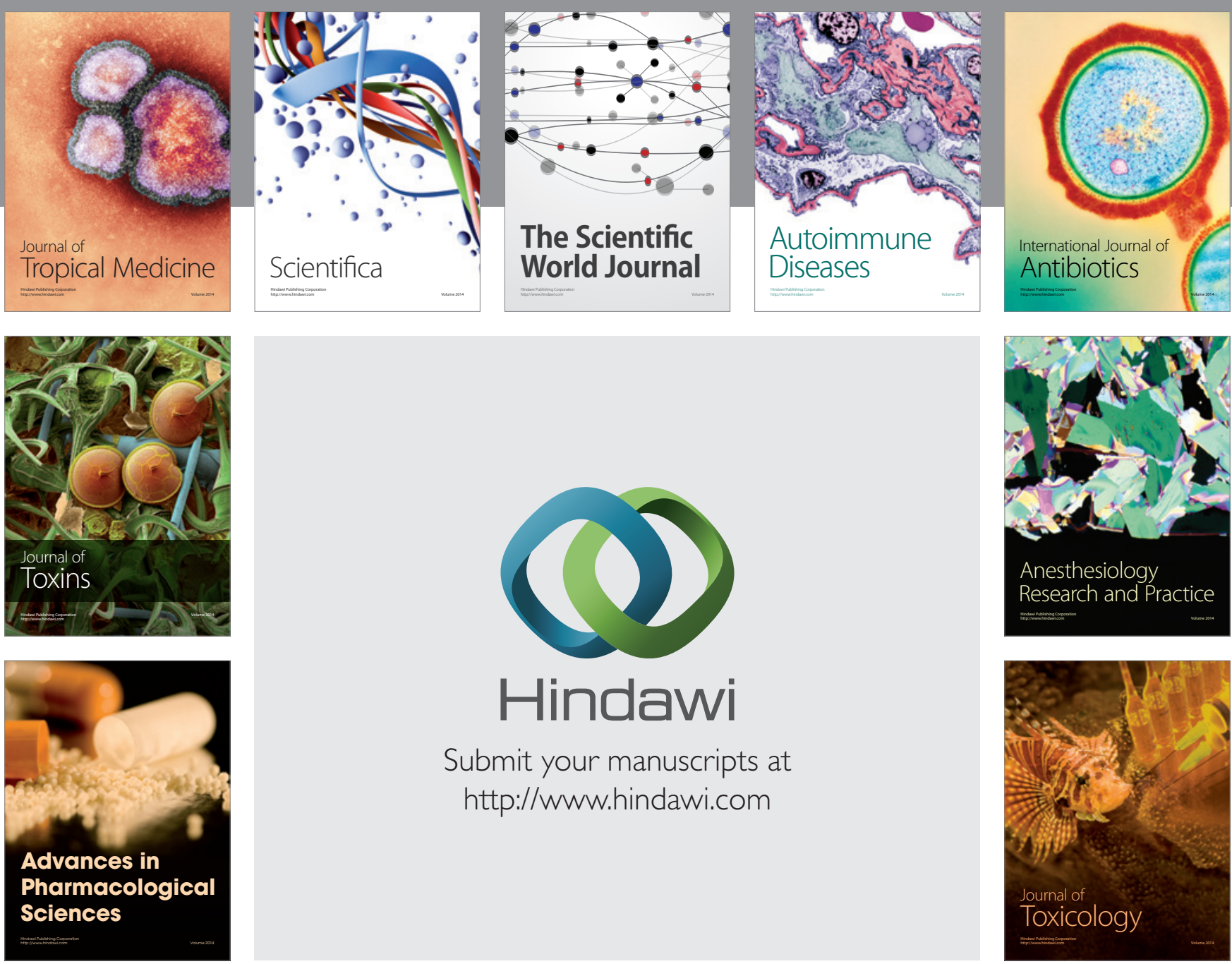

\section{Hindawi}

Submit your manuscripts at

http://www.hindawi.com
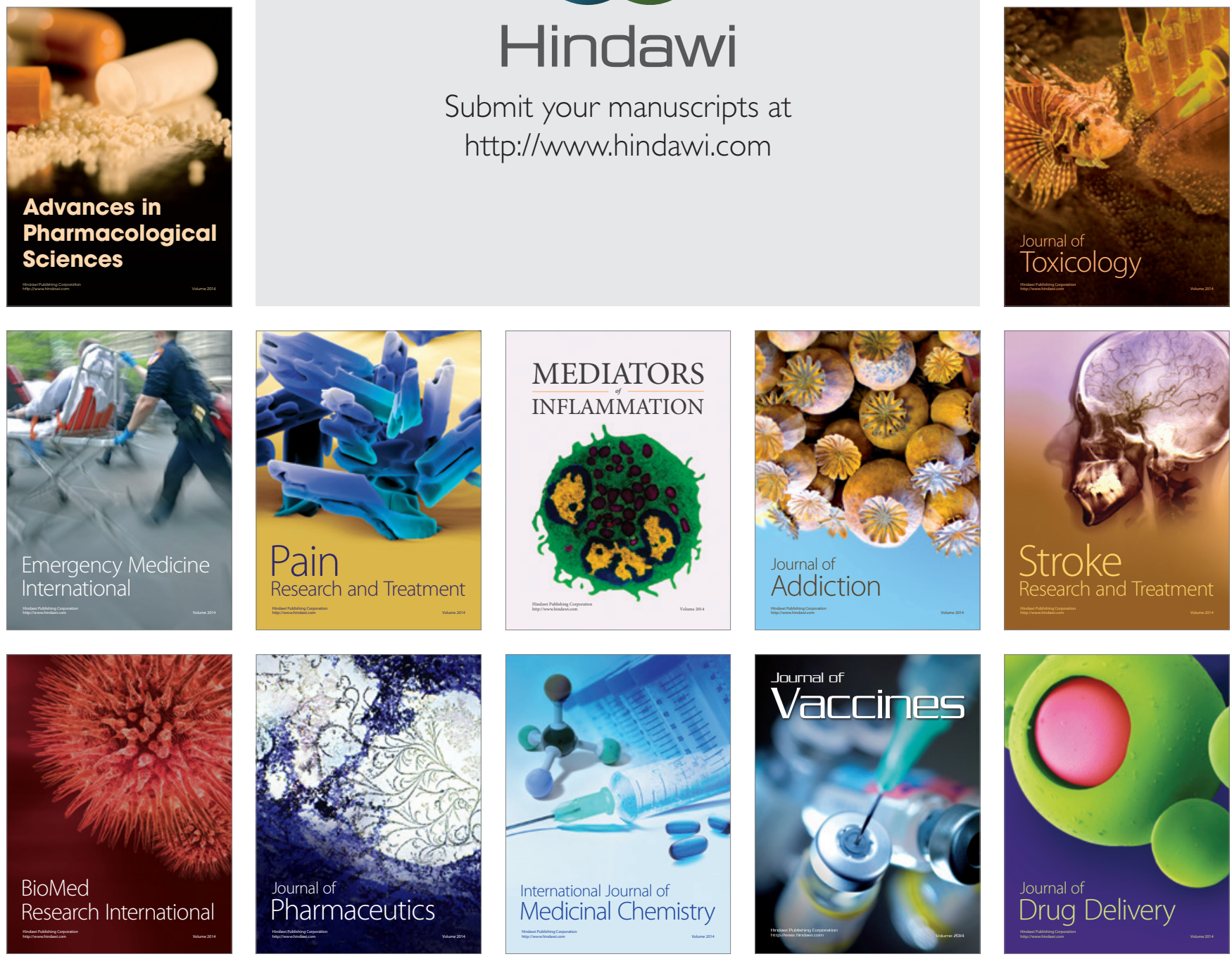